\title{
An outlook on ion signaling and ionome of mycorrhizal symbiosis
}

\author{
Alessandro C. Ramos ${ }^{1 *}$, Arnoldo R. Façanha ${ }^{2}$, Livia M. Palma ${ }^{3}$, Lev A. Okorokov ${ }^{1,3}$, Zilma M.A. \\ Cruz $^{4}$, Ary G. Silva ${ }^{4}$, Arthur F. Siqueira ${ }^{1}$, Amanda A. Bertolazi ${ }^{1,2}$, Gabriela C. Canton ${ }^{1}$, Juliana \\ Melo $^{1}$, Wolmen 0. Santos ${ }^{1}$, Vanusa M. B. Schimitberger ${ }^{1}$ and Anna L. Okorokova-Façanha ${ }^{3 *}$ \\ ${ }^{1}$ Laboratório de Microbiologia Ambiental e Biotecnologia, Centro Universitário Vila Velha, 29102-770, Vila Velha, \\ Espírito Santo, Brazil. \\ ${ }^{2}$ Laboratório de Biologia Celular e Tecidual \\ ${ }^{3}$ Laboratório de Fisiologia e Bioquímica de Microrganismos, Centro de Biociências e Biotecnologia, Universidade \\ Estadual do Norte Fluminense Darcy Ribeiro, Campos dos Goytacazes- RJ, 28013-602, Brazil. \\ ${ }^{4}$ Laboratório de Ecologia Vegetal, Centro Universitário Vila Velha, 29102-770, Vila Velha, Espírito Santo, Brazil.
}

*Corresponding authors: alessandro.ramos@uvv.br; anna@uenf.br

Received: 18 May 2010; Accepted: 26 September 2010

\section{ABSTRACT}

The 450-million-year-old interaction between the majority of land plants and mycorrhizal fungi is one of the most ancient, abundant, and ecologically important symbiosis on Earth. The early events in the evolution of mycorrhizal symbioses seem to have involved reciprocal genetic changes in ancestral plants and free-living fungi. New data on the mechanism of action of specific signaling molecules and how it influence and is influenced by the membrane ions fluxes and cytoplasm ion oscillations which integrate the symbiotic ionome are improving our understanding of the molecular bases of the mycorrhization process. This mini-review will highlight topics regarding what is known about the ionome and ionic communication in the arbuscular mycorrhizal symbiosis focusing on the signals involved in the development of symbioses. Here we present an overview integrating the available data with the prospects of the research in the field.

Key words: ion dynamics, íon signaling, mycorrhiza, ionomics, plant synapsis

\section{RESUMO}

A interação que se desenvolve há mais de 450 milhões de anos, entre a maioria das plantas terrestres e os fungos micorrízicos é uma das mais antigas, conspícuas e ecologicamente importantes simbioses na Terra. Os eventos iniciais na evolução da simbiose micorrízica parecem ter envolvido mudanças genéticas recíprocas nas plantas ancestrais e nos fungos de vida livre. Novos dados sobre o mecanismo de ação de moléculas sinalizadoras específicas destas interações, e de como estas influenciam e são influenciadas pelos fluxos de íons nas membranas e oscilações iônicas citoplasmáticas estão ampliando nossa compreensão das bases moleculares do processo de micorrização. Esta revisão destaca tópicos sobre 0 estudo do ionoma e da comunicação iônica da simbiose micorrízica enfocando os sinais envolvidos no desenvolvimento da simbiose. Uma visão geral da simbiose será apresentada refletindo a integração dos dados disponíveis com novas perspectivas para as pesquisa no campo.

Palavras chaves: dinâmica iônica, sinalização iônica, micorrizas, ionômica, sinapse em plantas 


\section{IONOME OF ARBUSCULAR MYCORRHIZAL INTERACTION}

The 450-million-year-old symbiosis between the majority of land plants and arbuscular mycorrhizal fungi is one of the most ancient, abundant, and ecologically important mutualisms on Earth (Pirozinsky and Dalpé, 1992; Remy et al., 1994). Through time, fungal endophytes and plants have become interdependent. Plants rely largely on fungi for soil nutrient uptake and some fungi even became obligate biotrophs unable to exist without a living host root.

As mycorrhizal fungi regulates the host plant ionome by modulating membrane transport proteins that control the nutrition and ion homeostasis of the host, influencing its ions and water absorption, growth, yield and disease resistance, whereas in turn, the host plant provides photoassimilates necessary for fungal energy supply, growth and reproduction. A descriptive approach has dominated the investigation of mycorrhizas for at least 50 years until the advent of molecular biology and the 'omics' era providing insights into the mechanisms of action of this symbiosis (Chabaud et al., 2011). The state-of-theart of the available molecular and genetic tools, coupled to high-throughput sequencing and advanced microscopy, have led to the genome and transcriptome analysis of the symbionts (Bonfante and Genre, 2010). Although, these studies have generated a huge amount of information, many uncharacterized genes have been found for which new approaches have to be applied in order to reveal the respective physiological roles. In this scenario, the ionomics has emerged as a powerful strategy to identify new aspects of ion homeostasis and ion dynamics to generate well-based hypothesis on putative functions of several uncharacterized genes (Eide et al., 2005).

Salt et al. (2008) defined the ionome as the mineral nutrient and trace element composition of an organism that represents the inorganic component of cellular and organismal systems. The ionomics, in turn, can be defined as the study of the ionome, which involves quantitative analysis and simultaneous measurements of the ionic composition of a living organism and of the changes in the concentration and composition in response to physiological stimuli, developmental state and environmental modifications.
The plant may perceive and respond to microbial invasion by sending the proper signals thus orchestrating a complex network of interactions; and most land plants can enter into symbioses with mycorrhizal fungi (Smith and Read, 2008). A number of features including fungal infection of the host plant, transcriptional activation of a subset of plant genes and formation of an intracellular interface where nutrient exchange occurs being the direct effect on host ionome (Stracke et al., 2002; Bidartondo et al., 2002; Genre et al., 2008; Bonfante and Genre, 2010). Actually, genetic and molecular analyses in the model legumes Medicago truncatula and Lotus japonicus identified multiple genes that are required for mycorrhizal symbiosis (Novero et al., 2002; Bais et al., 2004; Harrison, 2005; Maeda et al., 2006; Kiriachek et al., 2009). Merging information from transcriptomics, metabolomics and proteomics into consistent models, it will be possible to describe and predict the behaviour of biological systems, for example with respect to endogenous or environmental changes (Holger and Rainer, 2006). Ionomics of symbiotic interactions has the ability to capture information about the functional state of a host under different conditions, driven by genetic and developmental differences induced by mycorrhizal fungus (Williams and Salt, 2009).

This information combined to Multi-level approaches of transcriptional regulation, metabolite profiling and enzyme activity measurements are promising to prove how the relationships between symbiotic nutrients supply and metabolic adjustment in mycorrhizal symbiosis (Salt et al., 2008; Smith and Read, 2008). Evidences have been provided that external hyphae of arbuscular mycorrhizal fungi can deliver up to $80 \%$ of plant P, $25 \%$ of plant $\mathrm{N}, 10 \%$ of plant $\mathrm{K}, 25 \%$ of plant $\mathrm{Zn}$ and $60 \%$ of plant Cu (Marschnner and Dell, 1994). It is feasible that the external hyphae may have tightly regulated specific transport systems for each one of these ions, even that, until now only some $\mathrm{P}$ transporters have been well studied in mycorrhizal fungi.

\section{DEVELOPMENT OF ARBUSCULAR MYCORRHIZAL SYMBIOSIS}

The development of AM symbiosis starts before the physical contact between host plant roots and AM fungus, 
when spores in the soil germinates and recognize signals released by roots. These root factors induce hyphal growth and branching, followed by the differentiation of fungal adhesion structures (Harrison, 2005; Parniske, 2008). In turn, the plant responds to fungal signals with modifications in gene expression (Kosuta et al., 2003; Kuhn et al., 2010) and the organization of the prepenetration apparatus in hyphopodia-contacted cells (Genre et al., 2005, 2008; Chabaud et al., 2011). Actually, the term hyphopodium has been used and sometimes confused with appressorium. The genetic commonalities between appressorium and hyphopodium differentiation suggesting that hyphopodia could represent primitive appressoria, and so, hyphopodium formation (Figure 1) is likely to be an intermediate step before mature appressorium development.

Root exudates released by non-host plants cause neither hyphal differentiation nor appressorium formation (Giovannetti et al., 1993, 1997). It seems likely that the host root exudates contain specific active compounds, most of them yet unknown. The host roots signalling molecules that induce extensive hyphal branching in AM fungi are called "branching factors" (Buee et al., 2000; Akiyama et al., 2005). In turn, the AM fungi produce signaling molecules denominated "Myc factors", in analogy to the "Nod factors" from nitrogen-fixing symbiosis, which trigger physiological and cellular responses leading to root recognition and colonization (Kosuta et al., 2003).

Using a simple and elegant approach, Akiyama et al. (2005) purified the first branching factor (BF) from root exudates of Lotus japonicus, a strigolactone very effective at extremely low concentrations $\left(10^{-13} \mathrm{M}\right)$. Application of purified strigolactone as well as a synthetic derivate (GR 24) led to hyphal branching in Gigaspora margarita, however without any effect in Glomus intraradices. Strigolactones were previously used to stimulate or break the dormancy of seeds of parasitic plants, acting in a concentration-dependent and parasite species-specific manner (Nefkens et al., 1997; Yoneyama et al., 2001). It has been recently discovered that strigolactones are derived from the carotenoids, and should therefore be called apocarotenoids and not sesquiterpene lactones, as such are quite plant-specific (Matusova et al., 2005;
Lendzemo et al., 2005). Recently, it has been identified that strigolactones constitute a new hormonal signal that also regulates shoot branching (Umehara et al., 2008; Beveridge and Kyozuka, 2010; Domagalska and Leyser, 2011) and cell division in plants (Zhongyuan et al., 2010).

A possible interaction between mycorrhiza and parasitic plants through host plant, resulting in reduced infection by Striga of sorghum and maize colonized by AM fungi, was postulated (Lendzemo et al., 2005). Besserer et al. (2006) demonstrated the effect of strigolactones and synthetic derivatives (but no other sesquiterpene lactones) in three groups of AM fungi: Gigaspora rosea, Glomus intraradices, and Glomus claroideum. This widespread strigolactone perception system suggests that already the earliest land plants used this class of molecules to communicate with their symbiotic partners (Akiyama et al., 2005; Matusova et al., 2005; Besserer et al., 2006).

The intercellular hyphae develop highly branched arbuscular structures inside root cortex which penetrate root cell wall (Figure 1) and then invaginate in the host plasma membrane. The modified plant plasma membrane forms a periarbuscular membrane (PAM). The branching progression of the fungus into the host cell promotes de novo synthesis of PAM constituents which expands surrounding all the arbuscule (Gianinazzi-Pearson, 1996).

The nutrient exchange in the plant-fungal interfaces occurs in specific sites, where nutrients are absorbed from the soil by the fungus and transferred to the host plant, which in turn deliveries sugars to the fungal cells. It has been argued that the most intensive nutrient transfer activity occurs along the arbuscular interface and evidences have shown that polyphosphates (polyP), the plasma membrane $\mathrm{H}^{+}$-ATPase, and a myriad of secondary ion transporters have a key function during the nutrient exchange (Figure 2). Therefore, the intense flux of ions, sugars and amino acids takes place in the arbuscules and very likely in other cell-cell interfaces where plant and fungal pumps, secondary transporters and channels are functioning (Figure 2). At these sites are localized the main membrane systems responsible for the ion dynamics in association and regulating directly the host plant ionome. 


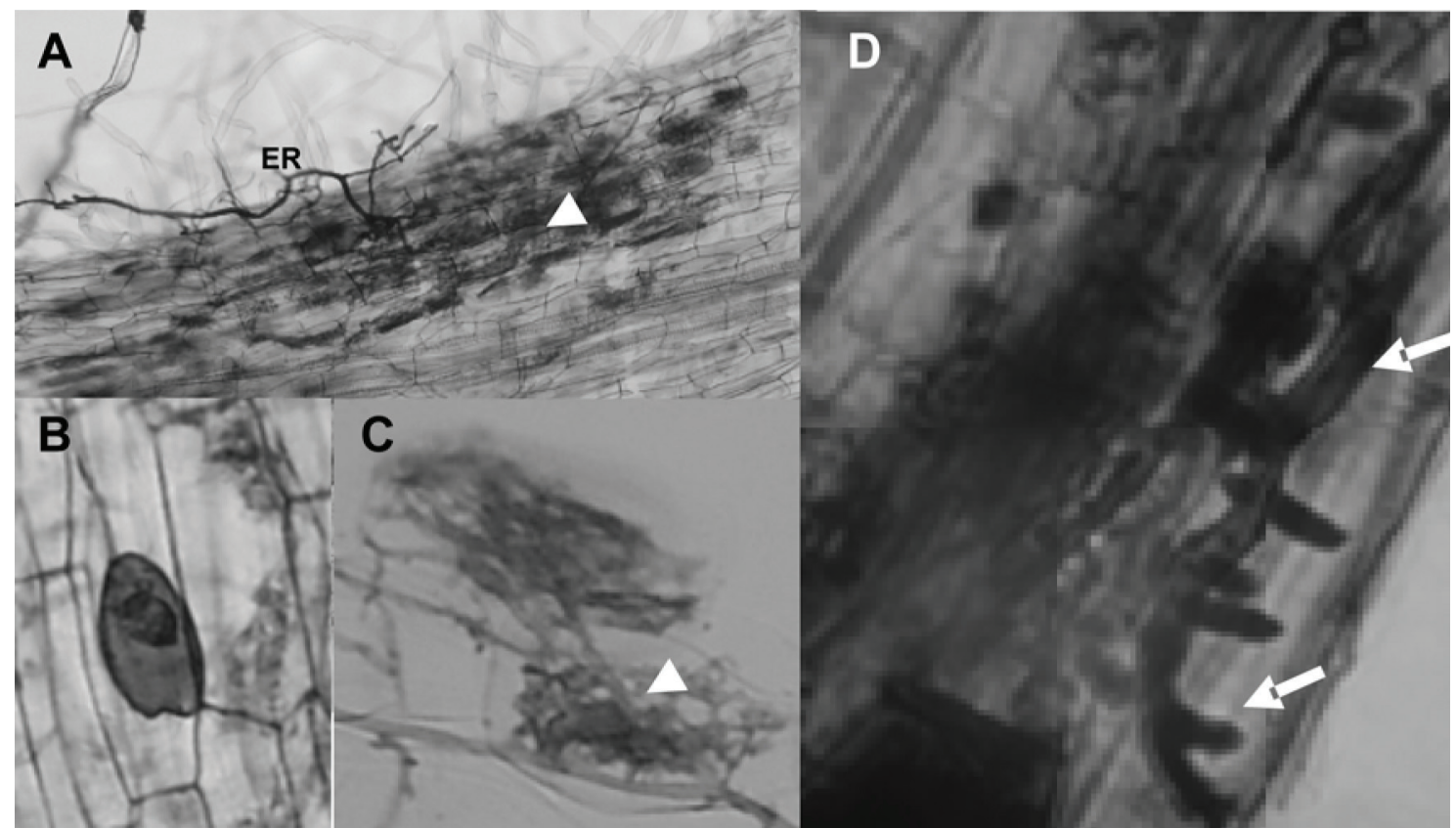

Figure 1. Functional mycorrhizal structures in roots of the plant host Solanum lycopersicum (Tomato). Fungal colonization was both inter- and intracellular and only involved the cortical cells of the roots. A, Root of S. Iycopersicum showing extraradical hyphae (ER), arbuscules (Arrowhead). B, Detail of a vesicle and arbuscule (C) of Glomus intraradices in S. Iycopersicum roots. (D) Hyphae of Glomus intraradices showing a typical hyphopodium (Arrows) or appressorium, at later stage, in the epidermal root cells.

Several pieces of evidence suggest that the $\mathrm{H}^{+}$-ATPase energize the periarbuscular membrane by generating an intercellular acidic compartment (Marx et al., 1982; Gianinazzi, 1991). Indeed, at molecular level, the up-regulation of $\mathrm{H}^{+}$ATPase genes by AM fungi has been extensively demonstrated (e.g., Gianinazzi-Pearson et al., 2000; Ferrol et al., 2002; Krajinski et al., 2002). However, there were some difficulties to detect the respective ATPase activation at functional level (McArthur and Knowles, 1993; Bago et al., 1997; Benabdellah et al., 1999). Nevertheless, evidences have been provided for the activation during the AM colonization process of not only of the plasmalema $\mathrm{H}^{+}$-ATPase but also of both tonoplast $\mathrm{H}^{+}$pumps (Ramos et al., 2005, 2009b).

Using a cell fractionation technique Tani et al. (2009) demonstrated that the polyP-synthesizing activity in an AM fungus is localized in the organelle and was not inhibited by bafilomycin A1, specific inhibitor of the vacuolar $\mathrm{H}^{+}$-ATPase. The authors also found higher P-type $\mathrm{H}^{+}$-ATPase activity in fractions with no polyP-synthesizing activity (Tani et al., 2009; Seufferheld and Curzi, 2010), suggesting that a localized high concentration of ATP can be important to the polyP synthesis.
It has been proposed that the relationship between long-chain and short-chain PolyPs within the host and fungi is correlated with mycorrhizal colonization (Takanishi et al., 2009). The length of polyP in mycorrhizal roots appeared to be shorter than in extraradical hyphae or in spores, indicating that AM fungus can depolymerize polyP before transfer Pi to the host plant (Ohtomo and Saito, 2005; Takanishi et al., 2009). The poly $\mathrm{P}$ content increased as colonization proceeded, and was highly correlated with the weight of the colonized roots (Seufferheld and Curzi, 2010).

Cruz et al. (2009) revised the nitrogen metabolism in AM symbiosis and demonstrates that before nutrient exchange interface, the nitrogen is taken up by the extra-root mycelium in the form of nitrate or ammonium, and incorporated in organic compounds by glutamine synthetase. The glutamine produced is fed into the anabolic arm of the urea cycle, leading to the synthesis of arginine, which is loaded into the vacuoles. It is then transported along the hyphae into the intra-root mycelium, where arginine moves out of the vacuole and is loaded into the anabolic arm of the urea cycle in order to be degraded, leading to an increased concentration of urea. In the presence 
of active urease, the urea can be transformed into ammonium and carbon dioxide (Cruz et al., 2009). Finally, nitrogen is transferred to the plant root in the form of ammonium (Bago et al., 2001; Govindarajulu et al., 2005; Cruz et al., 2007).

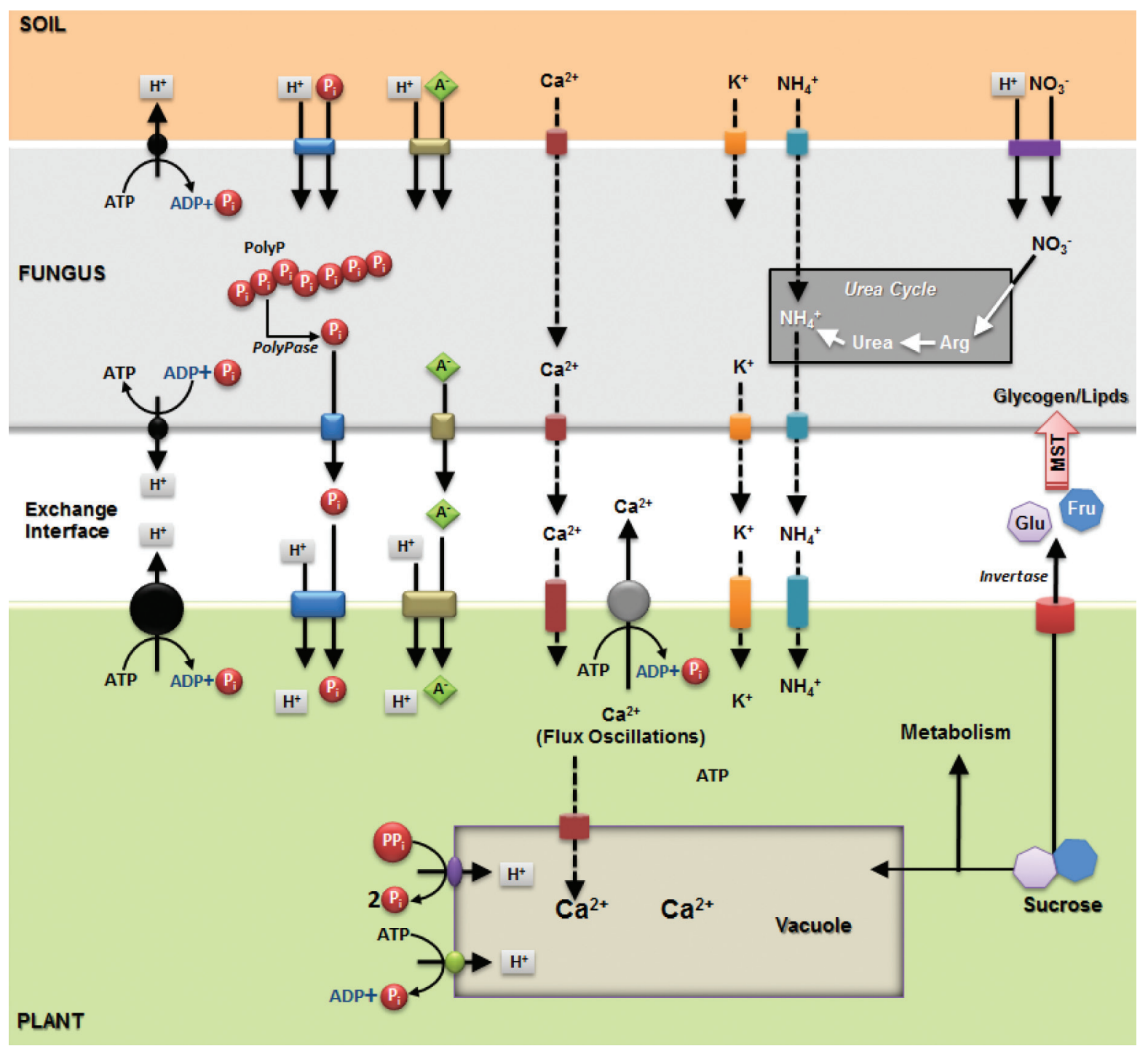

Figure 2. Schematic representation of the symbiotic synapse with the bidirectional nutrient exchangein arbuscular mycorrhizal interaction. These interfaces are formed in the space between the intercellular hypha wall and the cortical plant cell wall. The plasma membrane $\mathrm{H}^{+}$-ATPase of plant and fungal (black circles), phosphate transporters, Polyphosphate (PolyP) hydrolysed by PolyPhosphatase enzymes (PolyPases) and activity of fungal ion channels are represented. Both fungal and plant plasma membrane $\mathrm{H}^{+}$-ATPase extrude protons at the interface and out of the fungal cell creating an electrochemical gradient across the membranes that energizes the secondary transport of inorganic phosphate (Pi), ammonium $\left(\mathrm{NH}_{4}^{+}\right)$, nitrate $\left(\mathrm{NO}_{3}{ }^{-}\right.$), potassium $\left(\mathrm{K}^{+}\right)$, several anions $\left(\mathrm{A}^{-}\right)$, sucrose, glucose $(\mathrm{Glu})$ and fructose (Fru). Sucrose is hydrolyzed (probably by invertases) and sugars are transported to fungal cells through monosaccharide transporters (MST). Ca ${ }^{2+}$ flux oscillations and pH changes induce membrane depolarization during the ion uptake, resulting in $\mathrm{Ca}^{2+}$ and $\mathrm{H}^{+}$signatures specific for the stage of the mycorrhizal interaction.

CHANGES ON HOST AND FUNGAL IONOME: PROTON AND CALCIUM DYNAMICS

The mechanisms by which plants perceive and respond to endogenous and exogenous stimuli may depend on receptorlike proteins. The perception of microbial signals is believed to take place at the plant cell plasma membrane, activating cascades involving phosphorilation/dephosphorilation of enzymes and transcription factors that converge on the nucleus where transcriptional reprogramming facilitates the symbioses (e.g., Genre et al., 2005). 
Some types of receptors have been identified in EST data sets that can have a function in the plant-endophytic bacteria interaction. Most of the receptors exclusively or preferentially expressed in the infected libraries are receptor-like kinases, whose role in the symbiotic signal transduction pathway has recently been described, from the perception of microbial signalling molecules to rapid symbiosis-related gene activation (Stracke et al., 2002). Enzymes of the eukaryotic protein kinase superfamily catalyze the reversible transfer of the $\gamma$-phosphate from ATP to amino acid side chains of proteins. Protein kinases activity is antagonized by the action of protein phosphatases. The involvement of phosphatases during plantmicrobe interactions has already been demonstrated. Genes from the model legume Lotus japonicus, encoding a protein phosphatase type $2 \mathrm{C}$, had enhanced expression specifically in the nodules. Vargas et al. (2003) identified five ESTs encoding phosphatases and four ESTs encoding kinases exclusively or preferentially produced in the infected libraries; these proteins could possibly control signalling cascades in the association.

However, more than a few questions remain to be answered in order to utterly understand the signal transduction pathways leading to AM formation. Certainly we will benefit from the characterization of the Myc-factors, and the identification of new mutants impaired in different stages of AM development (Lima et al., 2009). It has been reported that the addition of Nod factors (NFs) stimulates mycorrhizal colonization suggesting the existence of a crosstalk between the signalling pathways leading to the formation of nodules and mycorrhizal (Parniske, 2008). DMI genes were identified as those that control calcium spiking and consequently NFs signalling pathway leading to nodulation, and it was demonstrated that they are also required for mycorrhiza formation (Kistner et al., 2005). It has been proposed that both intra and extracellular $\mathrm{Ca}^{2+}$ gradients are associated with the polarized growth of pollen tube (Holdaway-Clarke et al., 1997) and root hairs (Shaw and Long, 2003). The perception of the NFs by root hair cells involves increasing $\mathrm{Ca}^{2+}$ influx and intracellular alkalinization. However, the effect of $\mathrm{CO}_{2}$, strigolactone and NFs on the expression, activity and regulation of $\mathrm{AM}$ fungal $\mathrm{Ca}^{2+}$ permeable channels and other transport systems is still largely unknown (Ramos et al., 2008a,b). Recently, Chabaud et al. (2011) have found that $\mathrm{Ca}^{2+}$ spiking elicited by the fungal exudate in the responsive zone of the root is generally broader and more variable in width when compared with the relatively homogeneous spikes elicited by hyphopodium contact. This interesting difference found by Chaboud and colleagues indicates that the bio-active molecules released by the presymbiotic mycelium may differ from the fungal signals generated following hyphopodium differentiation on the outer root surface. However, it remains to be shown whether such differences in the pattern of $\mathrm{Ca}^{2+}$ spiking represent key determinants in transducing the respective symbiotic signals into appropriate cellular responses.

Plant responses to Nod-factors presence occur within minutes (1-10 min), including rapid changes in ion fluxes. These consist of $\mathrm{Ca}^{2+}$ influxes, followed by membrane depolarization and rhythmic cytoplasmic $\mathrm{Ca}^{2+}$ oscillations $\left(\mathrm{Ca}^{2+}\right.$ spiking) (Oldroyd and Downie, 2004). At the top of the signal perception transduction hierarchy are Nodfactor receptors, LysM type receptor kinases. This complex was identified in $L$. japonicus and contains two receptorlike kinases, LjNFR1 and LjNFR5, with LysM motifs in their extracellular domain, implicated in binding $\mathrm{N}$-acetylglucosamine-containing molecules (van Rhijn et al., 1997; Lima et al., 2009).

The finding that some legume mutants unable to form symbioses with nitrogen-fixing rhizobia (nod) were also unable to develop AM (myc), suggests that both symbioses share common regulatory mechanisms (Lima et al., 2009). It is well established that calcium $\left(\mathrm{Ca}^{2+}\right)$ signalling plays a major role in rhizobial Nod factors (NFs) signal transduction in the legume root prior to bacterial infection (Oldroyd and Downie, 2004). Nod factors addition to root hairs elicits a specific, regular $\mathrm{Ca}^{2+}$-spiking response which is a part of the signal transduction pathway leading to gene expression (Charron et al., 2004). In addition, the Mt DMI3 gene, which encodes a $\mathrm{Ca}^{2+}$, calmodulin-dependent kinase (Levy et al., 2004), acts downstream of $\mathrm{Ca}^{2+}$-spiking and is believed to interpret the $\mathrm{Ca}^{2+}$ spiking signal. The characterization of additional plant mutants has brought to light that two other genes, DMl1 and DMI3, are essential for both nodule and AM development (Ané et al., 2004; Riely et al., 2007). DMl1, a putative cation channel, acts downstream of DMI2/SYMRK and upstream of DMI3, and is probably involved in $\mathrm{Ca}^{2+}$ spiking (Oldroyd and Downie, 2004). The fact that DMI3 is essential for the establishment of both rhizobial and AM symbioses argues that $\mathrm{Ca}^{2+}$ signaling is also an important component of host signal transduction in the fungal/plant interaction. 
Modulations of the transport systems mediating not only $\mathrm{Ca}^{2+}$ but also $\mathrm{H}^{+}$ions influx and efflux seems to be a common upstream signalling system operating specific ion signatures for the plant symbiotic interactions. Actually, it has been shown that $\mathrm{pH}$ changes exert a profound effect on most biological processes, including nutrient uptake, cell growth and plantmicrobe interactions (Feijó et al., 1999; Felle, 2001; Michard et al., 2008). Previously, it was postulated by A.R. Façanha in the International Foundation for Science projects $(2003,2007)$ that specific spatial and temporal localized $\mathrm{H}+$ fluxes mainly driven by $\mathrm{H}+$-ATPases could delineates "proton signatures" involved in the signaling of the early events of the mycorrhizal interaction (AR Façanha, personal communication). The localization and regulation of the activity of $\mathrm{H}^{+}$pump isoforms during the symbiotic phase was assessed in the arbuscule by cytochemistry (Marx et al., 1982; Gianinazzi-Pearson et al., 1991) and immunolocalization using polyclonal antibodies (Gianinazzi-Pearson et al., 2000). Biochemical and electrophysiological analysis demonstrated the $\mathrm{H}^{+}$-pumps activation in mycorrhizas (Bago et al., 1997; Benabdellah et al., 1999; Ramos et al., 2005, 2009b). However, these studies were performed during symbiotic development and only two studies reported the identification and regulation of AM fungal $\mathrm{H}^{+}$-ATPase during the presymbiotic events (Ramos et al., 2008a,b). It was found that specific spatial and temporal regulated extracellular $\mathrm{H}^{+}$fluxes are indeed involved in both presymbiotic and symbiotic development of arbuscular mycorrhizal symbiosis (Ramos et al., 2008b).

Although, a possible impact of $\mathrm{pH}$ changes was not yet established for ectomycorrhizal associations, proton

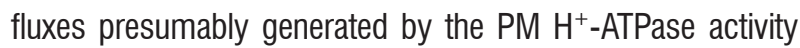
was shown to modify the root surface $\mathrm{pH}$ in a manner that triggers modifications in the availability of free extracellular $\mathrm{Ca}^{2+}$ or anion transport. Ramos et al. (2009a) also observed that external $\mathrm{Ca}^{2+}$ act as a strong inhibitor of the $\mathrm{H}^{+}$efflux and root surface acidification in the elongation zone of eucalypt roots. In contrast, they found that $\mathrm{Ca}^{2+}$ fluxes were also affected by the medium's $\mathrm{pH}$, as has previously been reported in other plant cells. Ramos et al. (2009a) proposed a model in which nutrient uptake and stimulation of growth are mediated by ectomycorrhizal fungi and may be $\mathrm{pH}$-dependent. Furthermore, the variations detected in ectomycorrhizal roots for proton and anion fluxes suggest a main contribution from the plant, while the results obtained for $\mathrm{Ca}^{2+}$ suggest a significant involvement of the fungus.

\section{FISSION YEAST AS A FUNGAL MODEL FOR ION SIGNALLING AND IONOME ANALYSIS}

A major factor hampering studies of the arbuscular mycorrhizal fungi, including that on the ionome and signal transduction, is the obligatory biotrophic nature of these fungi; so far, they have not been cultured in the absence of a plant host. On the other hand, the fission yeast Schizosaccharomyces pombe, which is widely used for studies of cell cycle and cell morphology, represents also an excellent fungi model to study cellular ion homeostasis (Façanha and Okorokova-Façanha, 2004). Many fundamental aspects of metal homeostasis, including the first insights into the yeast ionome, have already been elucidated in Saccharomyces cerevisiae (Eide et al., 2005). However, in several aspects the $S$. pombe micronutrient metabolism is fundamentally different from $S$. cerevisiae and closer to other eukaryotic organisms (Boch et al., 2008). Importantly, S. pombe genome was sequenced (Wood et al., 2002), the genes were annotated (Aslett and Wood 2006) and the collection of deletion mutants covering $99 \%$ of the fission yeast open reading frames (ORFs) was constructed (Spirek et al., 2010). Significant achievement towards our understanding of physiological role of encoded proteins was obtained by cloning of $S$. pombe protein-coding open reading frames (ORFeome), tagging each ORF with the yellow fluorescent protein and determination of localization of 4,431 proteins (Matsuyama et al., 2006).

Beyond the improvement of the major nutrients $\mathrm{N}, \mathrm{P}$ and $\mathrm{K}$, the $\mathrm{AM}$ fungi can play a key function in supplying micronutrients to the host plant, like $\mathrm{Zn}$ and $\mathrm{Cu}$ (Marschnner and Dell, 1994). However, the systems responsible for the micronutrients transport from soil to the hyphae and from the hyphae to the root cells are yet to be fully explored in mycorrhiza, and the individual genes and gene networks that influence the acquisition and utilization of these elements remain largely unknown. Important insights into the molecular biology of cellular metal homeostasis have been gained from work on S. pombe. Fission yeast is successfully used to study copper homeostasis (Labbé, 2010). The components of a novel eukaryotic heteromeric plasma membrane complex that is essential for high affinity copper transport were identified in S. pombe (Zhou and Thiele, 2001). Transcript profiling and a genetic screen employed to characterize the response of fission yeast cells to zinc deficiency led to identification of Zrt1, a ZIP transporter that is a central component of zinc homeostasis 
(Dainty et al., 2008). Besides, Zhf transporter mediates endoplasmic reticulum storage of zinc (Boch et al., 2008).

There is a growing number of evidence that calcium homeostasis has a profound effect on proton homeostasis and other ions like copper, iron and zinc (Kane, 2007, Cheng et al., 2005). In fact, the mutant deficient of $S$. pombe $P_{5^{-}}$ type ATPase Cta4 (Okorokova-Façanha et al., 2002) which exhibits drastic reduction in ATP-dependent $\mathrm{Ca}^{2+}$ transport in endoplasmic reticulum and elevation of cellular $\mathrm{Ca}^{2+}$ accumulation in cells, displays very low $\mathrm{H}^{+}$-pumping activity of $\mathrm{H}^{+}$-ATPase and low activity of $\mathrm{Ca}^{2+} / \mathrm{H}^{+}$exchangers, besides augmented production of ROS (Lustoza, 2010; LM Palma, personal communication). Also, this mutant displays sensitivity towards $\mathrm{Ca}^{2+}$ and $\mathrm{Mn}^{2+}$, and its growth is dependent on $\mathrm{Fe}^{3+}$ and $\mathrm{K}^{+}$(Okorokova-Façanha et al., 2002). These findings is not without precedence since the $S$. cerevisiae mutant in Spf1 ATPase, which is a homologue of Cta4 ATPase, was identified among 212 mutant strains (out of 4,385 mutants generated by the genome deletion project) exhibiting changes in yeast ionome (Eide et al., 2005). Thus, $P_{5^{-}}$ATPases are critical for the homeostatic control of several elements such as calcium, cobalt, copper, iron, magnesium, manganese, nickel, phosphorus, potassium, selenium, sodium, sulfur and zinc. S. pombe, and particularly Cta4 deficient mutant, represents an excellent tool to study the signaling pathways mediated by $\mathrm{Ca}^{2+}$ and ROS which regulate fungal ionome (Figure 3).

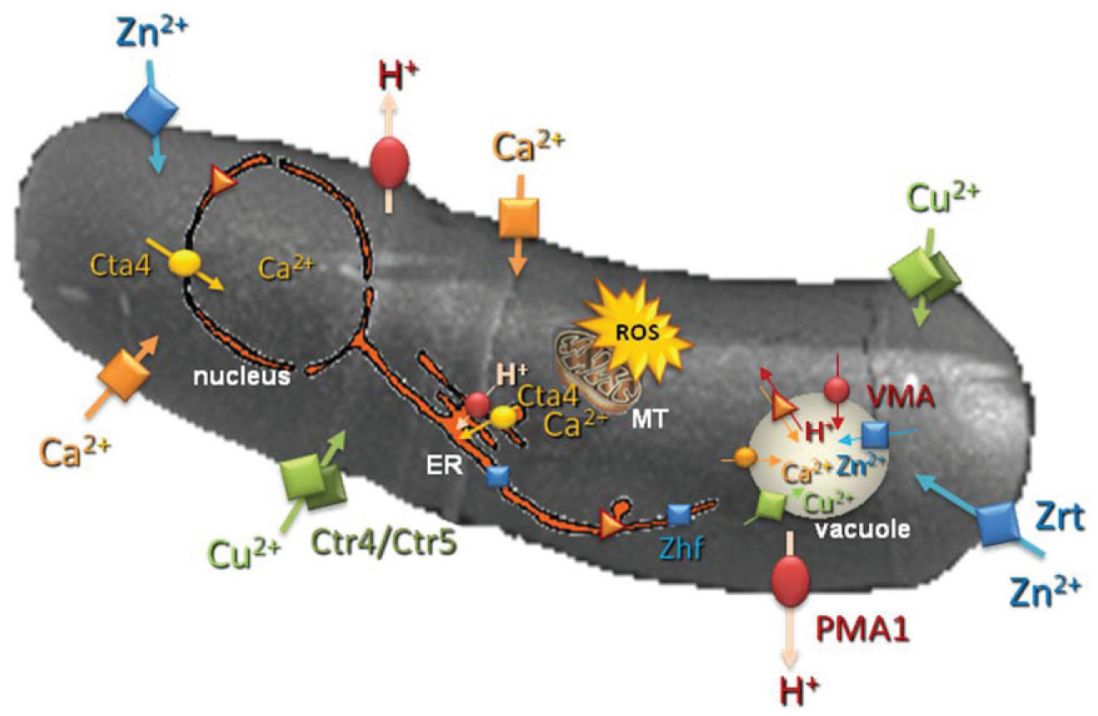

Figure 3. Schematic representation of some ion transporters and channels on the fission yeast Schizosaccharomyces pombe scanning microscopic image and the main cell compartments involved in $\mathrm{Ca}^{2+}$ and ROS signaling. Plasma membrane $\mathrm{Cu}^{2+}$ transporter is $\mathrm{Ctr} 4 / \mathrm{Ctr} 5$ complex; vacuole $\mathrm{Cu}^{2+}$ transporter is $\mathrm{Ctr6}$; plasma membrane $\mathrm{Zn}^{2+}$ transporter is $\mathrm{Zrt}$; endoplasmic reticulum $\mathrm{Zn}^{2+}$ transporter is Zhf. Cta4, endoplasmic reticulum $\mathrm{P}_{5 \mathrm{~A}}-\mathrm{ATPase}_{\mathrm{T}}$; PMA1, plasma membrane $\mathrm{H}^{+}$-ATPase; VMA, vacuolar $\mathrm{H}^{+}$-ATPase, ER, endoplasmic reticulum; MT, mitochondria.

\section{CONCLUSION}

In addition to the still-open question about the signal molecules produced by AM fungi and recognized by potential receptors, the widespread presence of bacteria inside or specifically associated with AM fungi suggests that many AM symbioses are tripartite associations. Analyzing the molecular bases of the dialogue between the three partners will be an amazing challenge.

The recent elucidation of the molecular identity and function of the basic components such as strigolactones,
Nod factors, ROS and other molecules involved in the signal transduction and energetic of mycorrhization and bacteria symbioses will expand our knowledge on the role of the signalling pathways involved in the control and regulation of these crucial plant-microorganism symbiosis. The data discussed here, are in line with the notion that both intra and extracellular ion waves, notably of $\mathrm{Ca}^{2+}$ and $\mathrm{H}^{+}$, are associated with the cell growth and responses to various environmental stimulus, including the main interactions among plants and the soil ecosystem. 
It will be very interesting to explore specific coordination between the $\mathrm{H}^{+}$and $\mathrm{Ca}^{2+}$ ions signatures as a common phenomena involved in the signaling pathways of the plant-microrganism symbiosis. An example is the positive response of root hair cells from legume plants to the Nod Factors, which induce increments on the $\mathrm{Ca}^{2+}$ influx and intracellular alkalinization probably due to increase in the activity of plasma membrane $\mathrm{H}^{+}$-ATPase. It seems clear that the expression of $\mathrm{H}^{+}$-ATPase genes and the cytosolic alkalinisation of AMF hyphae are specifically regulated in the presence of root factors. As accumulating evidences based on both plant and fungi gene regulation and ion homeostasis studies suggest that common host signalling mechanisms have been evolved between biological nitrogen-fixing and mycorrhizal symbiosis, it is tempting to speculate that $\mathrm{Ca}^{2+}$ and $\mathrm{H}^{+}$signatures as well as the respective ionomes could be involved in the ion signalling events regulating both interactions. Further comparative analysis among the genome and transcriptome of mycorrhizal fungi, host plants and the budding and fission yeasts are needed to expand the potential of these organisms as models for elucidation of the main ion transporters, enzymes and pathways that integrates the ionome and signalling of mycorrhiza.

Acknowledgements: We would like to acknowledge Frederico Eutrópio for the revision of the manuscript. ACR's laboratory is supported by grants from Conselho Nacional de Desenvolvimento Científico e Tecnológico (CNPq) (475436/2010-5 and 556630/2009-2); Fundação de Apoio à Ciência e Tecnologia do Espírito Santo (FAPES) (45434484/09) and Fundação Nacional de Desenvolvimento do Ensino Superior Particular (Funadesp) (\#07/10; \#09/11). Financial support to ARF was provided by International Foundation for Science (IFS), CNPq and Fundação de Amparo à Pesquisa do Estado do Rio de Janeiro (FAPERJ), and to ALOF by FAPERJ. LMP PhD fellowship was granted by CAPES. GCC, JM and WOS have been supported by Master's fellowship conceded by FAPES.

\section{REFERENCES}

Akiyama K, Matsuzaki K, Hayashi H (2005) Plant sesquiterpenes induce hyphal branching in arbuscular mycorrhizal fungi. Nature 435: 824-827.

Ané J-M, Kiss GB, Riely BK, Penmetsa RV, Oldroyd GED, Ayax C, Levy J, Debelle F, Baek J-M, Kalo P, Rosenberg C, Roe BA, Long SR, Denarie J, Cook DR (2004) Medicago truncatula DMl1 required for bacterial and fungal symbioses in legumes. Science 303: 1364
Aslett M, Wood V. (2006) Gene Ontology annotation status of the fission yeast genome: preliminary coverage approaches 100\%. Yeast 23: 913-919.

Bago B, Donaire JP, Azcón-Aguilar C (1997) ATPases activities of root from mycorrhizal sunflower (Helianthus annuus) and onion (Allium cepa) plants. New Phytol., 136: 305-311.

Bago B, Pfeffer P, Shachar-Hill Y (2001) Could the urea cycle be translocating nitrogen in the arbuscular mycorrhizal symbiosis? New Phytol 149: 4-8.

Bais HP, Park S-W, Weir TL, Callaway RM, Vivanco JM (2004) How plants communicate using the underground information superhighway. Trends Plant Sci. 9: 26-32.

Benabdellah K, Azcón-Aguilar C, Ferrol N (1999) Plasma membrane ATPase and $\mathrm{H}^{+}$transport activities in microsomal membranes from mycorrhizal tomato roots. J. Exp. of Bot. 50: 1343-1349.

Besserer A, Puech-Pagès V, Kiefer P, Gomez-Roldan V, Jauneau A, Roy S, Portais JC, Roux C, Becard G, Sejalon-Delmas N (2006) Strigolactones stimulate arbuscular mycorrhizal fungi by activating mitochondria. PLOS Biol. 4:e226

Beveridge CA, Kyozuka J ( 2010 ) New genes in the strigolactone- related shoot branching pathway . Curr. Opin. Plant Biol. 13: 34-39.

Bidartondo MI, Redecker D, Hiji I, Wiemken A, Bruns TD, Dominguez L, Sersic A, Leake JR, Read DJ (2002) Epiparasitic plants specialized on arbuscular fungi. Nature 419: 389-392.

Boch A, Trampczynska A, Simm C, Taudte N, Krämer U, Clemens S.(2008) Loss of Zhf and the tightly regulated zinc-uptake system SpZrt1 in Schizosaccharomyces pombe reveals the delicacy of cellular zinc balance. FEMS Yeast Res.8: 883-896

Bonfante P, Genre A (2010) Mechanisms underlying beneficial plant-fungus interactions in mycorrhizal symbiosis. Nature Commun. 4: 1-11.

Buee M, Rossignol M, Jauneau A, Ranjeva R, Becard G (2000) The presymbiotic growth of arbuscular mycorrhizal fungi is induced by a branching factor partially purified from plant root exudates. Mol. Plant-Microbe Interact. 13: 693-698

Chabaud M, Genre A, Sieberer BJ, Faccio A, Fournier J, Novero M, Barker DG, Bonfante P (2011) Arbuscular mycorrhizal hyphopodia and germinated spore exudates trigger $\mathrm{Ca}^{2+}$ spiking in the legume and nonlegume root epidermis. New Phytol. 189: 347-55.

Charron D, Pingret JL, Chabaud M, Journet EP, Barker DG (2004) Pharmacological evidence that multiple phospholipid signaling pathways link Rhizobium Nod factor perception in Medicago truncatula root hairs to intracellular responses including $\mathrm{Ca}^{2+}$ spiking and specific ENOD gene expression. Plant Physiol. 136, 3582-3593.

Cruz C, Egsgaard H, Trujillo C, Ambus P, Requena N, Martins-Loução MA, Jakobsen I (2007) Enzymatic evidence for the key role of arginine in nitrogen translocation by arbuscular mycorrhiza fungi. Plant Physiol. 144: 782-792.

Cruz C, Ramos AC, Façanha AR, Feijó JÁ, Martins-Loução MA (2009) Enzyme activity modulated by AMF colonization: the urea cycle and membrane-bound phosphatase activities. In: Ashok K. Chauhan and Ajit Varma. (Org.). Text Book on Molecular Biotechnology. 1 ed. I.K. International Publishing House Pvt. Chapter XVl: 1-1336.

Dainty SJ, Kennedy CA, Watt S, Bähler J, Whitehall SK. (2008) Response of Schizosaccharomyces pombe to zinc deficiency. Eukaryot Cell. 7:454-464.

Domagalska MA, Leyser 0 (2011) Signal integration in the control of shoot branching. Nature Rev. Mol. Cell. Biol. 12: 211-221.

Eide DJ, Clark S, Nair TM, Gehl M, Gribskov M, Guerinot ML, Harper JF (2005). Characterization of the yeast ionome: a genome-wide analysis of nutrient mineral and trace element homeostasis in Saccharomyces cerevisiae. Genome Biol 6:R77

Façanha AR, Okorokova-Façanha AL (2004) Aluminum tolerance mechanisms:

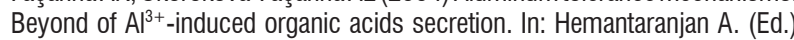
Advances in Plant Physiology. Vol. 7. Scientific Publishers (India). Chapter 13: $337-372$ 
Feijó JA, Sainhas J, Hackett GR, Kunkel JG, Hepler PK (1999) Growing pollen tubes posses a constitutive alkaline band in the clear zone and a growthdependent acidic tip. J. Cell Biol. 144: 483-496.

Felle HH (2001) pH: Signal and Messenger in Plant Cells. Plant Biol. 3: 577591.

Ferrol N, Pozo MJ, Antelo M, Azcon-Aguilar C (2002) Arbuscular mycorrhizal symbiosis regulates plasma membrane $\mathrm{H}^{+}$-ATPase gene expression in tomato plants. J. Exp. Bot. 53: 1683-1687.

Genre A, Chabaud M, Faccio A, Barker DG, Bonfante P (2008) Prepenetration apparatus assembly precedes and predicts the colonization patterns of arbuscular mycorrhizal fungi within the root cortex of both Medicago truncatula and Daucus carota. Plant Cell 20: 1407-1420.

Genre A, Chabaud M, Timmers T, Bonfante P, Barker DG (2005) Arbuscular mycorrhizal fungi elicit a novel intracellular apparatus in Medicago truncatula root epidermal cells before infection. Plant Cell 17: 3489-3499.

Gianinnazzi-Pearson, V (1996) Plant cell responses to arbuscular mycorrhizal fungi: getting the roots of symbiosis. Plant Cell, 8: 1871-1883.

Gianinazzi-Pearson V, Arnould C, Oufattole M, Arango M, Gianinazzi S (2000) Differential activation of $\mathrm{H}^{+}$-ATPase genes by an arbuscular mycorrhizal fungus in root cells of transgenic tobacco. Planta 211: 609-613.

Gianinazzi, S (1991) Vesicular-arbuscular (endo-)mycorrhizas: Cellular, biochemical and genetic aspects. Agric. Ecosyst. Environ. 35: 105-111.

Giovannetti M (1997) Host signals dictating growth direction, morphogenesis and differentiation in arbuscular mycorrhizal symbionts. In: Eukaryotism and Symsiosis, Eds. Schenk, Herrmann, Jeon, Muller, Schwemmler, Springer, pp.405-411.

Giovannetti M, Sbrana C, Avio L, Citernesi As, Logi C (1993) Differential hyphal morphogenesis in arbuscular mycorrhizal fungi during preinfection stages. New Phytol. 125: 587-593.

Govindarajulu P, Altwegg R, Anholt BR (2005) Matrix model investigation of invasive species control: bullfrogs on Vancouver Island. Ecol. Appl. 15:21612170.

Harrison MJ (2005) Signaling in the arbuscular mycorrhizal symbiosis. Annu. Rev. Microbiol. 59: 19-42.

Holdaway-Clarke TL, Feijo JA, Hackett GR, Kunkel JG, Hepler PK (1997) Pollen tube growth and the intracellular cytosolic calcium gradient oscillate in phase while extracellular calcium influx is delayed. Plant Cell 9, 1999-2010.

Holger $\mathrm{H}$, Rainer $\mathrm{H}$ (2006) On the way to understand biological complexity in plants: S-nutrition as a case study for systems biology. Cell. Mol. Biol. Lett. 11: $37-56$

Kane PM (2007) The long physiological reach of the yeast vacuolar $\mathrm{H}^{+}$ATPase. J Bioenerg Biomembr. 39: 415-421.

Kiriachek SG, Azevedo LCB, Peres LEP, Lambais MR (2009) Regulação do desenvolvimento de micorrizas arbusculares. Rev. Bras. Ciênc. Solo. 33:1-16

Kistner C, Winzer T, Pitzschke A, Mulder L, Sato S, Kaneko T, Tabata S, Sandal N, Stougaard J, Webb JK, Szczyglowski K, Parinske M (2005) Seven Lotus japonicus genes required for transcriptional reprogramming of the root during fungal and bacterial symbiosis. Plant Cell, 17:2217-2229.

Kosuta S, Chabaud M, Lougnon G, Gough C, Denarie J, Barker DG, Becard GA (2003) Diffusible factor from arbuscular mycorrhizal fungi induces symbiosis-specific MtENOD11 expression in roots of Medicago truncatula. Plant Physiol., 131:952-962.

Krajinski F, Hause B, Gianinazzi-Pearson V, Franken P (2002) Mtha1, a plasma membrane $\mathrm{H}^{+}$-ATPase gene from Medicago truncatula, shows arbusculespecific induced expression in mycorrhizal tissue Plant Biol. 4: 754-761.

Kuhn H, Küster H, Requena N (2010) Membrane steroid-binding protein induced by a diffusible fungal signal is critical for mycorrhization in Medicago truncatula. New Phytol. 185: 716-733.

Labbé (2010) Simon Labbé's work on iron and copper homeostasis. World J. .Biol. Chem. 1: 196-200.
Lendzemo VW, Kuyper TW, Kropff MJ, Van Ast A (2005) Field inoculation with arbuscular mycorrhizal fungi reduces Striga hermonthica performance on cereal crops and has the potential to contribute to integrated Striga management. Field Crops Res., 91: 51-61.

Levy J, Bres C, Geurts R, Chalhoub B, Kulikova O, Duc G, Journet EP, Ane JM, Lauber E, Bisseling T, Denaire J, Rosemberg C, Debelle F (2004) A putative $\mathrm{Ca}^{2+}$ and calmodulin-dependent protein kinase required for bacterial and fungal symbiosis. Science, 303:1361-1364.

Lima PT, Faria VG, Patraquim P, Ramos AC, Feijó JA, Sucena E, (2009) Plantmicrobe symbioses: new insights into common roots. BioEssays 31: 12331244.

Lustoza A C D M (2010) Cta4 ATPase e calcineurina regulam coordenadamente a função do reticulo endoplasmático e homeostase de cálcio em levedura de fissão. Tese (Doutorado em Biociências e Biotecnologia), Universidade Estadual do Norte Fluminense Darcy Ribeiro, Campos dos Goytacazes-RJ.

Maeda D, Ashida K, Iguchi K, Chechetka SA, Hijikata A, Okusako Y, Deguchi Y Izui K, Hata S (2006) Knockdown of an arbuscular mycorrhiza-inducible phosphate transporter gene of Lotus japonicus suppresses mutualistic symbiosis. Plant Cell. Physiol. 47: 807-817.

Marschner H, Dell B (1994) Nutrient uptake in mycorhizal symbiosis. Plant Soil, Dordrecht 159: 89-102.

Marx C, Dexheimer J, Gianinazzi-Pearson V, Gianinazzi S (1982) Enzymatic studies on the metabolism of vesicular-arbuscular mycorrhizas. 4. Ultracytoenzymological evidence (ATPase) for active transfer processes in the host-arbuscule interface. New Phytol. 90: 37-43.

Matsuyama A, Arai R, Yashiroda Y, Shirai A, Kamata A, Sekido S, Kobayashi Y, Hashimoto A, Hamamoto M, Hiraoka Y, Horinouchi S, Yoshida M. (2006) ORFeome cloning and global analysis of protein localization in the fission yeast Schizosaccharomyces pombe. Nat Biotechnol. 24:841-847.

Matusova R, Rani K, Verstappen FWA, Franssen MCR, Beale MH, Bouwmeester HJ (2005) The strigolactone germination stimulants of the plant-parasitic Striga and Orobanche spp are derived from the carotenoid pathway. Plant Physiol. 139: 920-934.

McArthur D, Knowles NR (1993) Influence of vesicular-arbuscular mycorrhizal fungi on the response of potato to phosphorus deficiency. Plant Physiol. 101: 147-160.

Michard E, Dias P, Feijó JA (2008) Tobacco pollen tubes as cellular models for ion dynamics: improved spatial and temporal resolution of extracellular flux and free cytosolic concentration of calcium and protons using pHluorin and YC3.1 CaMeleon. Sex. Plant Reprod. 21:169-181.

Nefkens JAC, Thuring JWFJ, Beenakkers MFM, Zwanenburg B (1997) Synthesis of phthaloylglycine-derived Strigol analogue and its germination stimulatory activity toward seeds of the parasitic weed Striga hermonthica and Orobanche crenata. J. Agr. Food Chem. 45: 2273-2277.

Novero M, Faccio A, Genre A, Stougaard J, Webb KJ, Mulder L, Parniske M, Bonfante P (2002) Dual requirement of the LiSym4 gene for mycorrhizal development in epidermal and cortical cells of Lotus japonicus roots. New Phytol. 154: 741-750.

Ohtomo R, Saito M (2005) Polyphosphate dynamics in mycorrhizal roots during colonization of an arbuscular mycorrhizal fungus. New Phytol 167:571-578.

Okorokova-Facanha AL, Appelgren H, Tabish M, Okorokov L, Ekwall K (2002) The endoplasmic reticulum cation P-type ATPase Cta $4 \mathrm{p}$ is required for control of cell shape and microtubule dynamics. J. Cell Biol. 157: 1029-1039

Oldroyd GE, Downie JA. (2004) Coordinating nodule morphogenesis with rhizobial infection in legumes. Annu. Rev. Plant Biol. 59: 519-546.

Parniske M (2008) Arbuscular mycorrhiza: the mother of plant root endosymbioses. Nature Rev. Microbiol., 6:763-775.

Pirozinsky, KA, Dalpé, Y (1992) The geological history of the Glomaceae with particular reference to mycorrhizal symbiosis. Symbiosis 7: 1-3. 
Ramos AC, Façanha AR, Feijó JA. (2008b) Proton $\left(\mathrm{H}^{+}\right)$flux signature for the presymbiotic development of the arbuscular mycorrhizal fungi. New Phytol. 178: $177-188$.

Ramos AC, Façanha AR, Lima PT, Feijó JA. (2008a) pH signature for the responses of arbuscular mycorrhizal fungi to external stimuli. Plant Signal. Behav. 3: 850-852.

Ramos AC, Lima PT, Dias PN, Kasuya MCM, Feijó JA (2009a) A pH signaling mechanism involved in the spatial distribution of calcium and anion fluxes in ectomycorrhizal roots. New Phytol. 181: 448-462.

Ramos AC, Martins MA, Façanha AR (2005) ATPase and pyrophosphatase activities in corn root microsomes colonized with arbuscular mycorrhizal fungi. Rev. Bras. Ciênc. Solo. 29: 207-213.

Ramos AC, Martins MA, Okorokova-Façanha AL, Olivares FL, Okorokov LA, Sepúlveda N, Feijó JA, Façanha AR. (2009b) Arbuscular mycorrhizal fungi induce differential activation of the plasma membrane and vacuolar $\mathrm{H}^{+}$pumps in maize roots. Mycorrhiza 19: 69-80.

Remy W (1994) 4-hundred-million-year-old vesicular-arbuscular mycorrhizae Proc. Natl. Acad. SCI. USA 11841-11843.

Riely BK, Lougnon G, Jean-Michel Ané, JM, Cook DR (2007) The symbiotic ion channel homolog DMl1 is localized in the nuclear membrane of Medicago truncatula roots. Plant J. 49: 208-216.

Salt DE, Baxter I, Lahner B (2008) Ionomics and the study of the plant ionome. Annu. Rev. Plant Biol. 59, 709-33.

Seufferheld MJ, Curzi MJ (2010) Recent Discoveries on the Roles of Polyphosphates in Plants. Plant Mol. Biol. Rep., 28: 549-559.

Shaw SL, Long SR (2003) Nod factor elicits two separable calcium responses in Medicago truncatula root hair cells. Plant Physiol 131: 976-984.

Smith, S.E, Read, D.J. (2008).Mycorrhizal symbiosis. 3.ed., London, Academic. 787p.

Spirek M, Benko Z, Carnecka M, Rumpf C, Cipak L, Batova M, Marova I, Nam M, Kim DU, Park HO, Hayles J, Hoe KL, Nurse P, Gregan J. (2010) S. pombe genome deletion project: an update. Cell Cycle 9:2399-2402.

Stracke S, Kistner C, Yoshida S, Mulder L, Sato S, Kaneko T, Tabata S, Sandal N, Stougaard J, Szczyglowski K, Parniske M (2002) A plant receptor-like kinase required for both bacterial and fungal symbiosis. Nature. 417: 959- 962.
Takanishi I, Ohtomo R, Hayatsu M, Saito M (2009) Short-chain polyphosphate in arbuscular mycorrhizal roots colonized by Glomus spp.: a possible phosphate pool for host plants. Soil Biol. Biochem. 41: 1571-1573.

Tani C, Ohtomo R, Osaki M, Kuga Y, Ezawa T (2009) Polyphosphatesynthesizing activity in extraradical hyphae of an arbuscular mycorrhizal fungus: ATPdependent but proton gradientindependent synthesis. Appl Environ Microbiol 75:7044-7050.

Umehara M, Hanada A, Yoshida S, Akiyama K, Arite T, Takeda-Kamiya N, Magome H, Kamiya Y, Shirasu K, Yoneyama K, Kyozuka J, Yamaguchi $S$ (2008) Inhibition of shoot branching by new terpenoid plant hormones. Nature 455: 195-200

van Rhijn P, Fang Y, Galili S, Shaul O, Atzmon N, Wininger S, Eshed Y, Lum M, Li Y, To V, Fujishige N, Kapulnik Y, Hirsch AM (1997) Expression of early nodulin genes in alfalfa mycorrhizae indicates that signal transduction pathways used in forming arbuscular mycorrhizae and Rhizobium-induced nodules may be conserved. Proc. Natl. Acad. Sci. USA 94:5467-5472.

Vargas C, De Pádua VLM, Nogueira ED, Vinagre F, Masuda HP, Da Silva FR, Baldani JI, Ferreira PCG, Hemerly AS (2003) Signaling pathways mediating the association between sugarcane and endophytic diazotrophic bacteria: A genomic approach. Symbiosis. 35: 159-180.

Williams L, Salt DE (2009) The plant ionome coming into focus. Current Opinion in Plant Biology 12: 247-249.

Wood V, Gwilliam R, Rajandream MA, Lyne M, Lyne R, Stewart A, Sgouros $J$, Peat N, Hayles J, et al and Nurse P (2002). The genome sequence of Schizosaccharomyces pombe. Nature. 415:871-880.

Yoneyama K, Takeuchi, Y, Yokota T (2001) Production of clover broomrape seed germination stimulants by red clover root requires nitrate but is inhibited by phosphate and ammonium. Physiologia Plantarum, 112:25-30.

Zhongyuan H, Haifang Y, Jinghua Y, Shinjiro Y, Masahiko M, Itsuro T, Nobuhiro T, JK, Mikio N (2010) Strigolactones negatively regulate mesocotyl elongation in rice during germination and growth in darkness Plant Cell Physiol. 51: 1136-1142.

Zhou H, Thiele DJ (2001) Identification of a novel high affinity copper transport complex in the fission yeast Schizosaccharomyces pombe. J Biol Chem. 276: 20529-20535. 